PNL-SA-25579

\title{
AMORPHIZATION OF COMPLEX CERAMICS BY HEAVY-PARTICLE IRRADIATIONS
}

\author{
R. C. Ewing ${ }^{(a)}$ \\ L. M. Wang ${ }^{(a)}$ \\ W. J. Weber
}

November 1994

Presented at the

Materials Research Society Annual Fall

Meeting

November 27 - December 2, 1994

Boston, Massachusetts

Prepared for

the U.S. Department of Energy

under Contract DE-AC06-76RLO 1830

Pacific Northwest Laboratory

Richland, Washington 99352

(a) Department of Earth and Planctary Sciences, University of New Mexico, Albuquerque, New Mexico

\section{DISCLAIMER}

This report was prepared as an account of work sponsored by an agency of the United States Government. Neither the United States Government nor any agency thereof, nor any of their employees, makes any warranty, express or implied, or assumes any legal liability or responsibility for the accuracy, completeness, or usefulness of any information, apparatus, product, or process disclosed, or represents that its use would not infringe privately owned rights. Reference herein to any specific commercial product, process, or service by trade name, trademark, manufacturer, or otherwise does not necessarily constitute or imply its endorsement, recommendation, or favoring by the United States Government or any agency thereof. The views and opinions of authors expressed herein do not necessarily state or reflect those of the United States Government or any agency thereof. 


\section{DISCLAIMER}

Portions of this document may be illegible in electronic image products. Images are produced from the best available original document. 


\title{
AMORPHIZATION OF COMPLEX CERAMICS BY HEAVY-PARTICLE IRRADIATIONS
}

R.C. EWING*, L.M. WANG*, W.I. WEBER**

* Depart of Earth and Planetary Sciences, U. of New Mexico, Albuquerque. NM 87131

* Facific Northwest Laboratory, Richland, WA 99352

\begin{abstract}
"Complex" ceramics, for the purpose of this paper, include materials that are generally strongly bonded (mixed innic and covalent), refractory and frequenuly gond insulators. Thcy are distinguished from simple, compact ceramics (e.g., $\mathrm{MgO}$ and $\mathrm{UO}_{2}$ ) by structural featurcs which include: 1.) open network structures, best characterized by a consideration of the shape, size and connectivity of coordination polyhedra; 2.y generally, complex compositions which characteristically lead to multiple cation sites and lower symmetry; 3.) directional bonding; 4.) bond-type variations, from bond-to-bond, within the structure. The heavy particle irradiations not only include ion-beam iradiations, but also recoil-nucleus damage iesulting from $\alpha$-decay events from constituent actinides. The latter effects are responsible for the radiation-induced transformation to the metamict state in minerals. The responses of these materials to irradiation are complex, as energy may be dissipated ballistically by transfer of kinetic energy from an incident projectile or radiolytically by conversion of radiation-induced electronic excitations into atomic motion. This results in isolated Frenkel defect pairs, defect aggregates, isolated collision cascades or bulk amorphization; all may occur concurrenty. Thus, the amorphization process is heterogeneous. Only recently have there been systcmatic studies of heavy particle irradiations of "complex" ceramics on a wide variety of stmucture-types and compositions as a function of dose and temperature. In this paper, we rcview the conditions for amorphization for the tetragonal orthosilicate, zircon $\left[\mathrm{ZrSiO}{ }_{4}\right]$; the hexagonal orthosilicate/phosphate apatite structure-type $\left[\mathrm{X}_{10}\left(\mathrm{ZO}_{4}\right)_{6}(\mathrm{~F}, \mathrm{Cl}, \mathrm{O})_{2}\right]$; the isometric pyrochlores $\left[\mathrm{A}_{1-2} \mathrm{~B}_{2} \mathrm{O}_{6}(\mathrm{O}, \mathrm{OH}, \mathrm{F}]_{0-1 \mathrm{p}} \mathrm{H}_{2} \mathrm{O}\right]$ and its monoclinic derivative zirconolite $\left[\mathrm{CaZ} \tau \mathrm{Ti}_{2} \mathrm{O}_{7}\right]$; the olivine (derivative - hcp) strucnure types, $\alpha-\mathrm{V}_{\mathrm{A}_{2}} \mathrm{NBO}_{4}$, and spinel (ccp), $\gamma_{-} \mathrm{V}_{\mathrm{A}_{2}} \mathrm{~N}_{\mathrm{BO}}$.
\end{abstract}

\section{INTRODUCTION}

The earliest recognition of radiation effects in materials was in a "complex ceramic", the naturally occurring mineral gadolinite $\left[(\mathrm{Ce}, \mathrm{La}, \mathrm{Nd}, \mathrm{Y})_{2} \mathrm{Fe}^{2+} \mathrm{Be}_{2} \mathrm{Si}_{2} \mathrm{O}_{10}\right]$. Jacob Bcrzelius noted the release of storcd energy on heating during blow-pipe analysis. Gadolinite is a shcet siltcate in which $\mathrm{SiO}_{4}$ and $\mathrm{BeO}_{4}$ tetrahedra form sheets parallel to the $(001)$ plane. The sheets are connected by $\mathrm{FeO}_{6}$ octahedra, and rare-earth clements are in 8-fold coordination. In 1893 , W.C. Brogger defined "metamikte" minerals as a third class of amorphous materials, but it was not until 1914 (18 years after the discovery of radioactivity) that Hamberg suggested that metamictization is a radiation-induced, periodic-to-aperiodic phasc transition caused by $\alpha-$ particles which originate from the constituent radionuclides in the uranium and thorium decay series. By 1924, V.M. Goldschmidt had provided the first criteria for metamictization which presaged the criteria of Naguib and Kelly [1] nearly 50 years later for simpler compounds that were arnorphized by ion-beam irradiations. In 1939, Stackelberg and Rottenback tricd to test the hypothesis that metamictization was a radiation-induced phase transformation by bombarding a thin slab of zircon with a-particles. The results were inconclusive but this must have been one of the first experiments in which an "ion beam" was uscd to "modify" a ccramic material. The details of this early history are summarized in refs. [2-4].

Most recently, systematic studies have been completed on a wide variety of silicate,

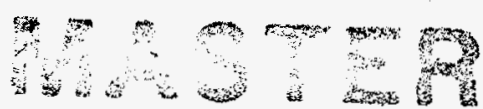


phosphate, and oxide structure types which have been amorphized by $\alpha$-decay event damage [5-7] or by ion-beam irradiations [8-10]. This review focuses on selectcd results which best exumplify the characteristics of "complex" ceramics. The basic approach involves lue detailed study of carefully selccted structure rypes over a wide range of compusitions. Structure types are considered on the basis of their topologic relations, e.g., zircon and apatite are both orthosilicates/phosphates (the tetrahedral monomers are not connected to one another, but rather are linked across comers and edges to nther cation courdination polyhedra). Ideally, pulymorphous structures of the same composition (e.g., the $\alpha$ - and $\gamma$-forms of $\mathrm{Fe}_{2} \mathrm{SiO}_{4}$ which are respectively the olivine (derivative $h c p$ ) and spinel (ccp) structure types) may be studied to determine the critical amomhization dose as a function of structure-type and temperature. This allows for the analysis of the structural and topologic controls on the final damage microstructure and critical amorphization dose [11]. For each structure type compositional variations allow the evaluation of the role of bond-type and bond-strength. As an cxample, in the olivine structure, the tetrahedral sites may be comprised of $\mathrm{SiO}_{4}, \mathrm{GeO}_{4}$, or $\mathrm{PO}_{4}$ tetrahedral monomer units. Thesc substitutions can dramatically change the calculated ionicity. The compositional substitutions also have dramatic effects on the physical and chemical properties. The melting point of $\mathrm{Mg}_{2} \mathrm{SiO}_{4}$ is $1890^{\circ} \mathrm{C}$ vs. $1,205^{\circ} \mathrm{C}$ for $\mathrm{Fe}_{2} \mathrm{SiO}_{4}$. The pressure-induced olivine-to-spinel transition occurs at approximately $150 \mathrm{~kb}$ for $\mathrm{Mg}_{2} \mathrm{SiO}_{4}$ and at $50 \mathrm{~kb}$ for $\mathrm{Fe}_{2} \mathrm{SiO}_{4}$. Thus, careful selection of the structure-type and composition can be used to analyze the important controlling parameters in the amorphization process.

Finally, one should comment on the fine previous studies [rers. 1 and 12 are good examples] and very recent exciting work [13-15]. The initial studies [1, 12] were, by and large, restricted to a consideration of binary compounds most of which are compact ceramics (e.g., $\mathrm{Al}_{2} \mathrm{O}_{3}$ and $\left.\mathrm{UO}_{2}\right)$. More recent studies [13-15] have focuscd on binary intermetallic compounds of various stoichiometries and with some variety in their structure types. In these compounds, disordeting on crystallographic sites (exchange of atoms) and the introduction of isolated defects are important processes. The principal advantage of studying the intermetallic coinpounds is that interatomic potentials are available, and this allows molecular dynamic simulations of the radiation-induced amorphization, as well as the calculation of elcctron diffraction patterns for comparison to actual experiments. The resulting model, derived from the study of intermetallic compounds, has been used to place radiation-induced amomhization into the wider context of processes that cause solid-state amorphization by establishing the thernodynamic relationships between static atomic displacements (i.e., expansion of the unit cell), melting, and elastic softening [15]. Although similar phenomenon have been observed for complex ceramics (e.g., expansion of the unit cell, correlation to melting point, and dramatic decreases in elastic modulus with increasing dose), it is not yct possible to extend the model to the description of complex ceramics. In particular, the radiation-induced amorphization in complex ceramics is heterogeneous. The transition from the periodic to aperiodic state occurs over a range of doses with a distinctive microstructurc, mixed aperiodic and periodic domains, the proportions of which change with increasing dose.

\section{STRUCTURE TYPES}

\section{Zircon}

Zircon (7.rSiO4) is the most cxtensively studied metamict mineral and "complex" ceramic. Zircon is tetragonal, $141 /$ amd, $(\mathrm{Z}=4)$. The zircon structure (Fig. 1) consists of edge-sharing $\mathrm{ZrO}_{8}$ dodecahedra forming chaits parallcl to [010] and chains of alternating, edge-sharing, $\mathrm{SiO}_{4}$ tetrahedral monomers and $2 \mathrm{rO}_{8}$ coordination polyhedra parallel to [001]. The chains are crosslinked by isolated $\mathrm{SiO}_{4}$ tetrahedra forming an open network structure.

Natural zircons containing up to $5,000 \mathrm{ppm} U$ and $T h$ undergo a radiation-induced 


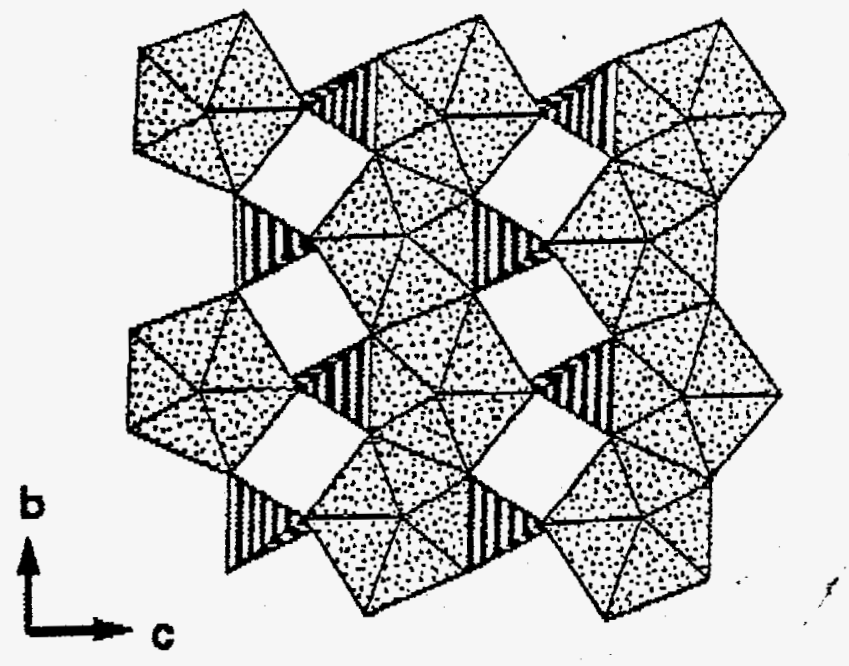

Figure 1. Structure of zircon as seen down [100] axis. Edge-shating dodecahedra (8-coordinated $\mathrm{Zr}_{\mathrm{r}}$, dotted) form chains parallel to [010]. The chains are cross-linked by $\mathrm{SiO}_{4}$ tetrahedra (striped).

crystalline-to-amorphous transfomation as a result of $\alpha$-decay event damage $[7,16]$. This transformation has also been studicd in synthetic zircon in which 238 Pu has been incorporated on $8.1 \%$ of the $\mathrm{Zr}$ sites $[6,17,18]$ and in situ by ion-beam-irtadiation of natural zircon crystals $[18,19]$. Amorphization from $\alpha$-decay cvent damage is complete after $1 \times 10^{19} \alpha$-decay events/g ( $-0.6 \mathrm{dpa}$ ) for both natural zircons and for Pu-doped zircon, even though the dose rates differ by $10^{8}$. Data analysis indicatcs that amorphization in zircon occurs as a result of defect accumulation rather than directly in the displacement cascades of the recoil nuclei $[6,17]$. This crystalline-to-amorphous transformation is shown in Fig. 2. The contributions of defect accumulation in the crystalline phase and volume change associated with the crystallineto-amorphous transformation to the total macroscopic swelling has been modeled $[17,18]$.

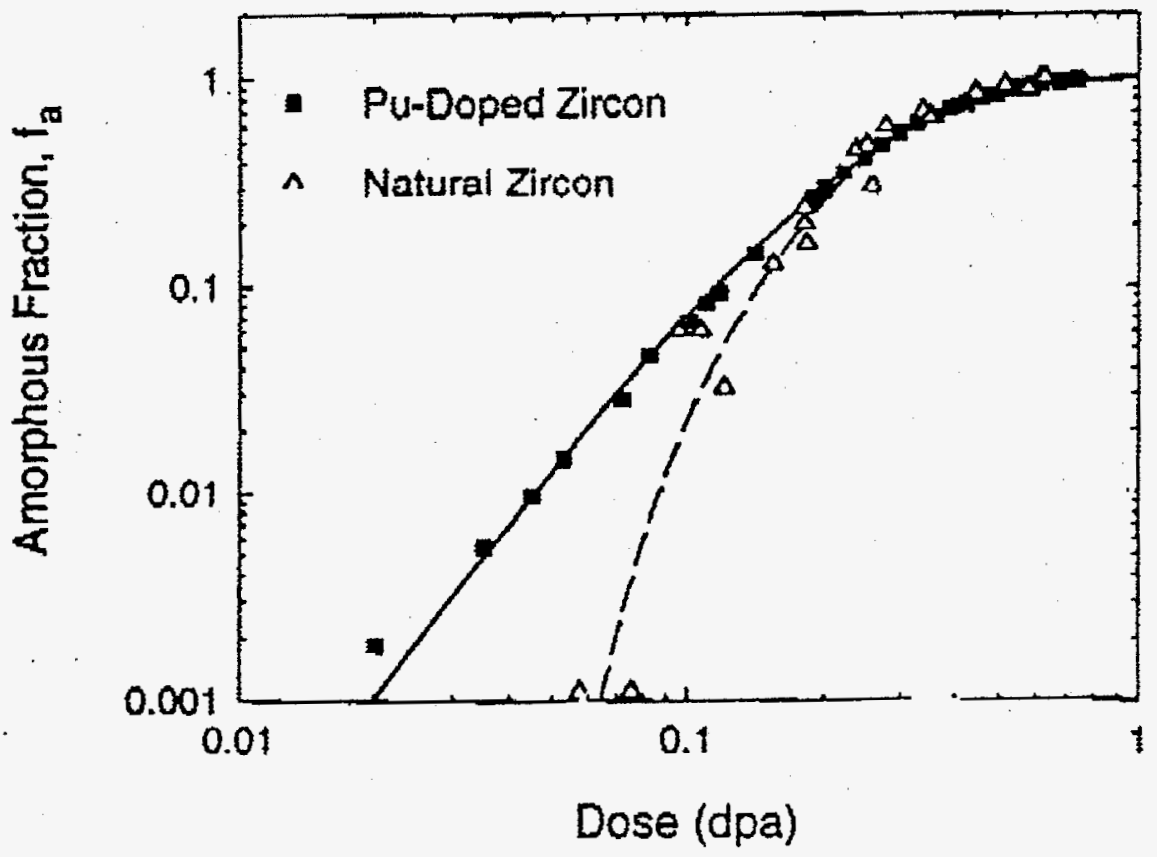

Figure 2. Amorphous fraction, $\mathfrak{f}_{a}$, as a function of dose in Pu-doped and natural zircons. The solid curve for Pu-doped zircon is based on a fit of the dala to a doublc overlap model [18]. The dashed curve for natural zircon is bascd on a fit of the double overlap model, with an incubation dose (0.05 dpa), to the optical and density data of Holland and Goltricd [16]. 
Based on thermal recovery data [6], the volume change associated with the fully amorphous statc in zitcon does not exhibit a significant temperature dependence. The dose for complete aromphization under heavy ion $\left(\mathrm{Kr}^{+}\right.$and $\left.\mathrm{Xc}^{+}\right)$irmadiation is the same as that jetermined for natural and Pu-doped zircon. In addition, high-rcsolution IEM indicates that the microstructural changes with duse are the sume for natural and $\mathrm{Kr}^{+}$-irradiated zircon. The temperature dependenee of amorphization in xircon tas been determincd in situ under $\mathrm{Kr}_{\Gamma}$ irradiation (Fig. 3) and may be understood as a two stage process in which different annealing mechanisms dominate [18]. The dose for amorphization increascs with temperature in two stages with activation energies of 0.02 and $0.31 \mathrm{eV}$, respectively, for the recovery processes.

The process for irradiation-induced amorphization in zitcon is now well understood. Models for the dose and temperature dependence (Fig. 3) of the amorphization process in zircon have been developed [18]. Consequently, it is possible to model the cffect of temperature and time on recovery kinetics for the amorphization process in zircon, and similar structures, over geologic time periods (i.c., hundreds of millions of years). This is significant because zircon is an important mineral for geochronological studies, and radiation damage may lead to disturbed $\mathrm{U}$ and $\mathrm{Pb}$ isotopic ratios. Additionally zircon has been identified as an actinide host phase in ceramic nuclear waste forms [20]. The work summarized herc confirms that radiation damage over geologic time scales can be simulated in crystalline waste forms by shorter term actinide-doping or ion beam-irradiation experiments.

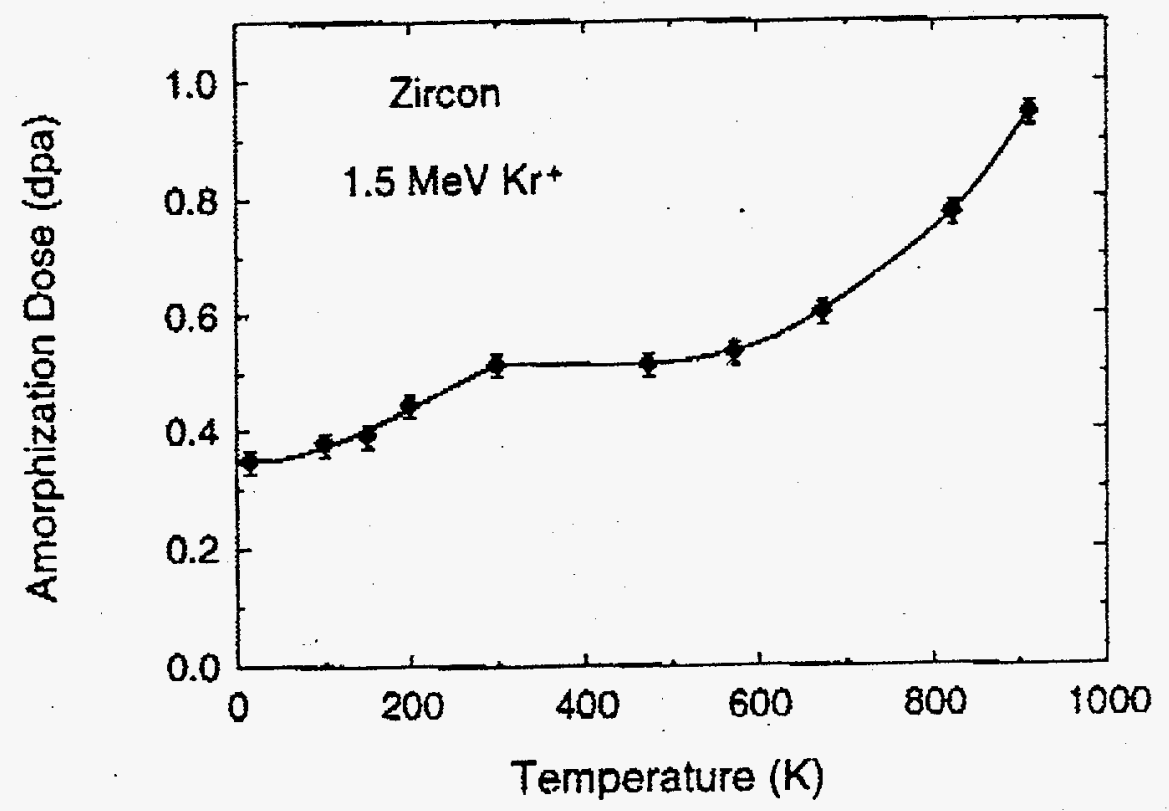

Figure 3. Temperature dependence of the dose for complete amophization of zircon under 1.5 $\mathrm{MeV} \mathrm{Kr}^{+}$irradiation. [18]. The data show two stages associated with defect annealing that decrease the rate of amorphization.

\section{Apatite Strucure Type}

The apatite group of minerals are the most abundant of the phosphate mincrals and include fluorapatite, $\mathrm{Ca}_{10}\left(\mathrm{PO}_{4}\right)_{6} \mathrm{~F}_{2}$, and hydroxyapatite, $\mathrm{Ca}_{10}\left(\mathrm{PO}_{4}\right)_{6}(\mathrm{O}, \mathrm{H})_{2}$, which arc the materials of teeth and bone [21]. Scveral rare-earth orthosilicatcs are isostructural with natural apatites. and those with the composition, $\mathrm{Ca}_{2}(\mathrm{La}, \mathrm{Nd}, \mathrm{Gd})_{8}\left(\mathrm{SiO}_{4}\right)_{6} \mathrm{O}_{2}$, have becn studied because of their ccurrence in nuclear waste forms.

Orthophosphatc and orthosilicate apatites are hexagonal, $\mathrm{P63} / \mathrm{m}, \quad(\mathrm{Z}=2)$. The $\mathrm{PO}_{4}$ or $\mathrm{SiO}_{4}$ 
tetrahedra are isolated from one another, but linked by larger cations. There are two asymmetric large cation sites for which $2 / 5$ of the large cations (usually $\mathrm{Ca}$ ) are surrounded by six closest oxygens in the form of trigonal prisms and $3 / 5$ of the cation sites are coordinated by five oxygens and one $F$. The resuling structure is a complex, open framework.

In situ irradiation of hydroxyapatite and carbunate-substituted apatite at rnom temperature in a TEM with $200 \mathrm{keV}$ eleutrons results in the rapid formation (<5 min) of hexagonallyshaped voids (1.5 to $10 \mathrm{~nm}$ in diameter) on the anion sublattice as a result of $F$ center aggregation [22]. After longer periods of electron irradiation (>20 min), local amorphization and collapse of the apatite structure occurs; however, complete amorphization has not been reported. Selected area electron diffraction indicates that polycrystalline $\mathrm{CaO}$ may form as a decomposition product within the amorphous matrix. A similar susceptibility to electronirradiation damage at room temperature has been reported for fluorapatite [23]; however, the void-like structures coalesced, forming a complex labyrinth with channels or voids $5 \mathrm{~nm}$ in diameter and amorphization was not observed. Ion-beam irradiation of fludoppatitc does result in amorphization, and the dose for amorphization increases with ternperature [24].

Irradiation-induced amorphization in rare-earth silicate isomorphs of natural apatite was frrst observed in Cm-doped glass [25] and ceramic [26] waste forms. Extensive investigations of $\alpha$-decay-induced amorphization in $\mathrm{Cm}$-doped $\mathrm{Ca}_{2} \mathrm{Nd}_{8}\left(\mathrm{SiO}_{4}\right)_{6} \mathrm{O}_{2}[17,27]$ and ion-beaminduced amorphization in $\mathrm{Ca}_{2} \mathrm{Lag}_{2}\left(\mathrm{SiO}_{4}\right)_{6} \mathrm{O}_{2}$ [28] have been completed. Unlike zircon, amorphization in $\mathrm{Cm}$-doped apatite primarily occurs directly in the cascade of the recoi] nucleus released by $\alpha$-decay. This amorphization results in significant volume expansion (up to $9.5 \%)$, storcd energy $(130 \mathrm{~J} / \mathrm{g})$, increased fracture toughness, and enhanced dissolution. The contributions of defect accumulation and amorphization to the total macroscopic swelling have also been determined and modeled [17]. The temperature dependence of amomphization under 1.5 MeV $\mathrm{Kr}+$ ion irradiation has been determined for both $\mathrm{Ca}_{2} \mathrm{La}_{8}\left(\mathrm{SiO}_{4}\right)_{6} \mathrm{O}_{2}$ and Iuoroapatite, $\mathrm{Ca}_{10}\left(\mathrm{PO}_{4}\right)_{6} \bar{F}_{2}$, (Fig. 4). The dose for completc amorphization increases more rapidly with temperature and exhibits no distinct stages for the fluorgapatite. In the case of $\mathrm{Ca}_{2} \mathrm{La}\left(\mathrm{SiO}_{4}\right)_{6} \mathrm{O}_{2}$, amorphization increases with temperature in two stages [28], similar to the

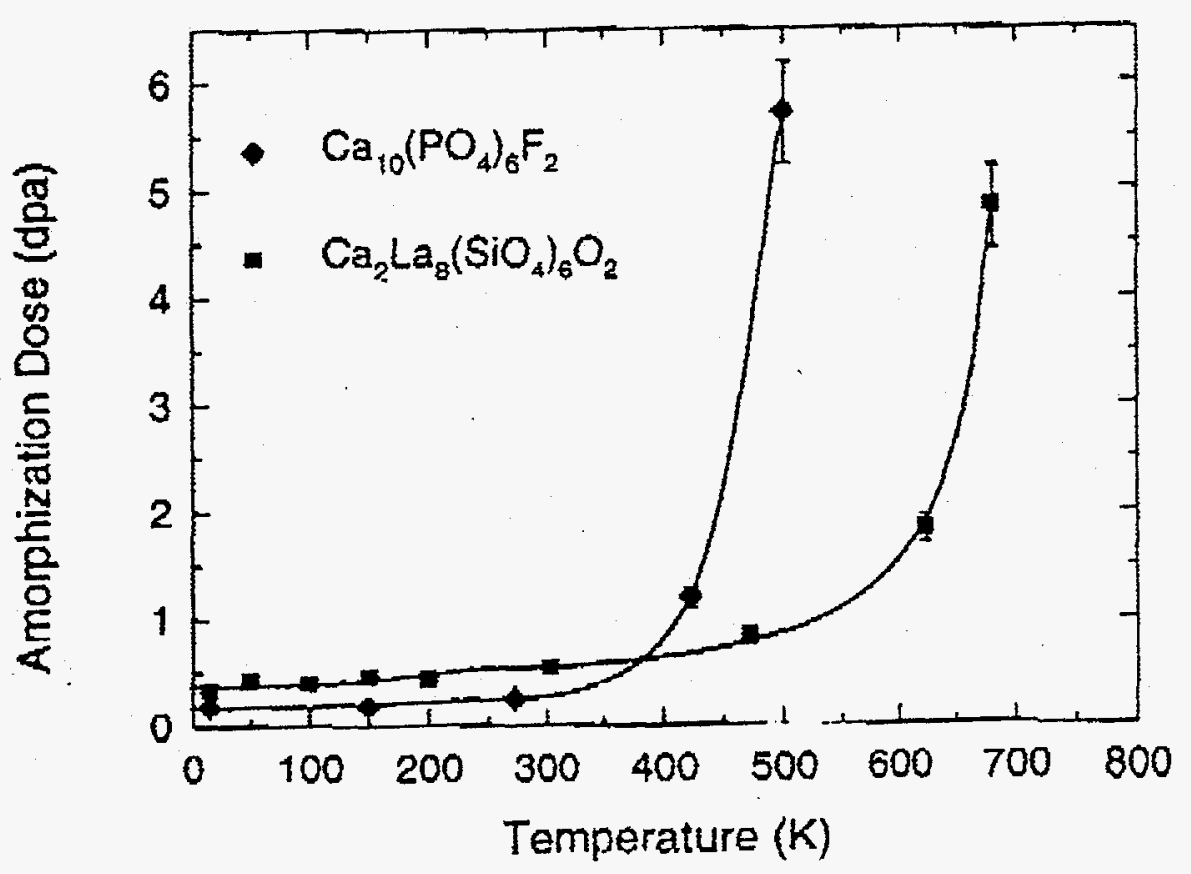

Figure 4. Comparison of temperature dependence of critical amorphization doses in displacement per atom (dpa) for $1.5 \mathrm{MeV} \mathrm{Kr}+$ inn-irradiated apatite structure types [24]. 
behavior in zircon. Given the same structure and identical irradiation condilions, the difference in the temperature dependence for the two apatile compositions (Fig. 4) is due to the higher ratc of recovery (more mobile defects, fewer cation species) for the flunrtiapatite. At $15 \mathrm{~K}$, the dose for cnmplate amorplization in $\mathrm{Ca}_{2} \mathrm{Lay}_{4}\left(\mathrm{SiO}_{4}\right)_{6} \mathrm{O}_{2}$ is independent of ion mass (recoil-energy spectrum) for $\mathrm{Ne}^{+}, \mathrm{Kr}^{+}$and $\mathrm{Xe}^{+}$ion irradiations [28]. As the temperature increascs, the dose for complete amorphization increases inversely with the mass of the bombarding ion.

\section{Byrochlore and Zirconolite}

The pyrochion structure-type, isometric $\mathrm{A}_{1-2} \mathrm{~B}_{2} \mathrm{O}_{6}(\mathrm{O}, \mathrm{OH}, \mathrm{F})_{0-1}$, encompasses more than 500 synthetic compositions and occurs in a wide variety of compositions in nature (pyrochlore, betafite and microlite are the principal minerals). The structure is similar to that of fluorite, but rather than the $\mathrm{AX}_{2}$ stoichiometry, one-eighth of the anions are missing and there are two cation sites. The main framework of the pyrochlore structure consists of $\mathrm{BO}_{6}$ octahcdra which share corners to form six-and three-membered rings' in sheets parallel to the (111) plane. The large A-site cations are in 8-fold coordination polyhedra [29]. The different polytypes, such as monoclinic zirconolite (Fig.5) are a result of different stacking sequences for the $\mathrm{BO}_{6}$ sheets. Despite a wide variety of potentially useful properties (catalytic activity, ferroelcctricity, ferromagnetism, luminescence, ionic conductivity, and high themal stability), the study of radiation effects has been restricted nearly exclusively to the monoclinic derivative, zirconolite $\left[(\mathrm{CaZ}) \mathrm{Ti}_{2} \mathrm{O}_{7}\right]$ which is an actinide-host phase in Ti-bascd, crystallinc ceramics. In waste form zirconolite, Pu, $\mathrm{Cm}$ and Am may occupy the A-site. For compositions such as (Ca.Pu) $\mathrm{Ti}_{2} \mathrm{O}_{7}$ a cubic pyrochlore structure forms. Radiation damage studics of natural, as well as $238 \mathrm{Pu}$ - and ${ }^{244} \mathrm{Cm}$-doped, pyrochlore and xirconolite have been summarized in detail by Ewing et al. [30].

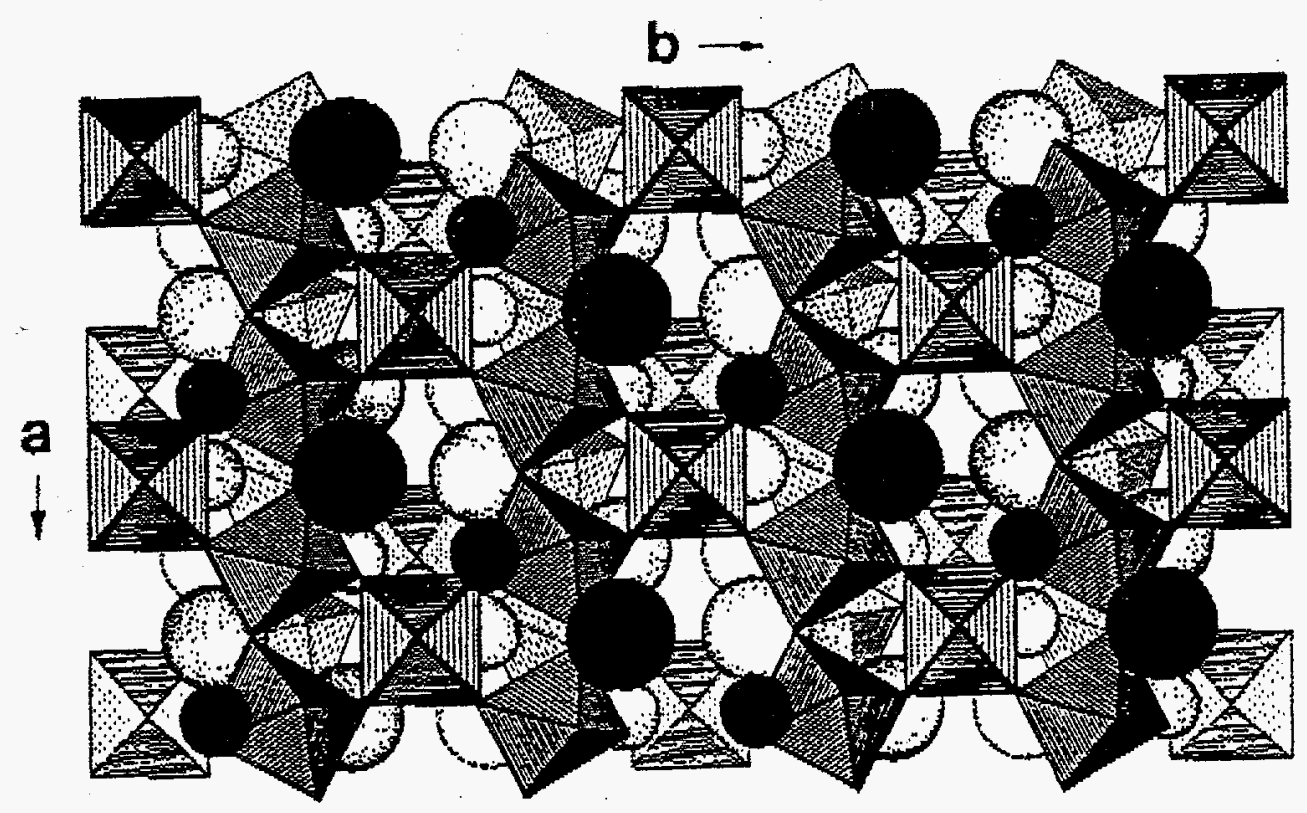

Figure 5. Polyhedral structure diagram of zirconolite in the $(001)$ projection, that is looking down on the sheets of comer-sharing $\mathrm{TiO}_{6}$. The octahedra represent $\mathrm{TiO}_{6}$; the small spheres. $\mathrm{Zr}$; the large spheres, $\mathrm{Ca}$ [30]. Crysal structure diagram courtesy of B.C. Chakoumakos.

In this review, we will only discuss the resulss of lon beam-iradiation experiments, which have only been completed on the zirconolite structure. TEM studies of samples irradiated with $3 \mathrm{MeV} \mathrm{Ar}{ }^{+}$ions showed damage buildup similar to that observed in material damaged by $\alpha$. 
decay of $238 \mathrm{Pu}$ or ${ }^{244} \mathrm{Cm}$, namely, accumulation of small defects ( $\alpha$-recoil tracks) to the point where the material became globally disondered [31]. The most recent study has been un a suite

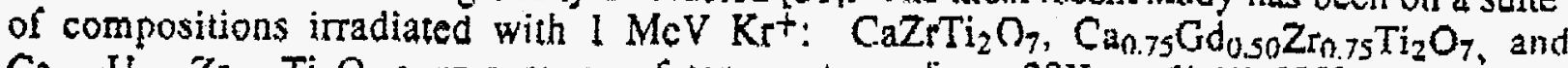
$\mathrm{Ca}_{0.75} \mathrm{U}_{0.5 n} \mathrm{Zr}_{0.75} \mathrm{Ti}_{2} \mathrm{O}_{7}$ over a range of temporatures frum $20 \mathrm{~K}$ w $675 \mathrm{~K}$ [32]. The most interesting result was the wide range of critical doses for amorphization. At $475 \mathrm{~K}$. the pure zirconolite required nearly an order of magnitude higher dose than the Gd-doped zirconolite. The uranium-doped zirconolite was amorphized by the fon milling, $4 \mathrm{kV} \mathrm{Ar}$, during sample preparation. This suggests that the susceptibility to amorphization of a nuclear waste form zirconolite may be sensitive to the composition, particularly the content of high- $Z$ actinides.

Natural zirconotites have also been used in ion-beam irradiation simulations of $\alpha$-decay event-induced amorphization [33]. Recrystallized samples (1,400 K for 8 hours in air) werc irradiated with $1.5 \mathrm{MeV} \mathrm{Kr}{ }^{+}$ions using the HVEM-Tandern Facility at Argonne National Laboratory. The $\mathrm{Kr}^{+}$dose rate used during the irradiation was $3.4 \times 10^{11}$ ions/ $\mathrm{cm}^{2} \mathrm{~s}$. which is a damage rate $2 \times 10^{12}$ times higher than that which has occurred in the natural zirconolite due to decay of uranium. In-situ transmission electron microscopy was completed curring the ion irtadiation. After a $\mathrm{Kr}^{+}$dose of $4 \times 10^{14}$ ions/ $\mathrm{cm}^{2}(=0.3 \mathrm{dpa})$, the circonolite grains werc amorphized. The dpa level for ion beam-induced amorphization is six times lower than that calculated for the natural ofdecay induced process. Some of the decay event damage may have recovered by point defect migration over geologic periods of time. Inclusions of thorianite, $\mathrm{ThO}_{2}$, in the zirconolite did not become amorphous at cquivalent doses. This is consistent with the already mentioned apparent radiation "resistance" of $\mathrm{UO}_{2}$. The resistance of thorianite to amorphization compared to zirconolite is consistent with a model of damage accumulation in insulators in which the critical dose for amorphization is inversely proportional to the topologic and chemical complexity of the phase [8]. Thorianite is isometric with only one unique cation site. Zirconolite is monoclinic with threc unique cation sites. Such criteria may be useful in evaluating the response of waste form ceramics to $\alpha$-dccay cvent damage.

Dose-dependence of damage in zirconolite has been studied by Headley et al. [34] using $\mathrm{Pb}^{+}$ions of 40 to $240 \mathrm{keV}$ at ambient tcmperature. The amorphization process is heterogeneous and proceeded in four stages: isolated tracks, track overlap, domination by aperiodic domains, and tinally complete amorphization. Results wcre compared with those for natural zirconolite sclf-irradiated to various damage levcls by $\alpha$-decay over gcologic times. Both the nature and extent of damage werc similar, regardless of the large difference in damage rates. Clinard ct al, [35] extended the comparison to include ${ }^{238} \mathrm{Pu}$-substituted zirconolite and showed that damage at the intermediate rate characteristic of zirconolite was similar to that observed in natural and $\mathrm{Pb}+$ ion-bombarded material.

In summary, these prelininary studics confirm the efficacy of using heavy ion-beam irradiations to simulate the longer-tem radiation effects that result from $\alpha$-decay event damage in nuclear waste forms. Systematic studies of zirconolites of variable composition over a range of temperatures should provide the necessary infomation for perfomince assessments as a function of waste form composition, themal history, and cumulative $\alpha$-decay event dose.

\section{$\mathrm{A}_{\mathrm{BO}} \mathrm{B}_{4}$ Cormpounds: Olivince Spinel and Phenakite}

The $\mathrm{A}_{2} \mathrm{BO}_{4}$ system is characterized by a rich variety of compositions (e.g., $\mathrm{A}=\mathrm{Mg}, \mathrm{Fc}$, $\mathrm{Mn}, \mathrm{Ca}, \mathrm{Ni}, \mathrm{Co}, \mathrm{Be}, \mathrm{Li}$, and $\mathrm{REE} ; \mathrm{B}=\mathrm{Si}, \mathrm{Gc}, \mathrm{Be}$ and $\mathrm{P}$ ), extensive solid-solutions between pure, cnd-member compositions, and a variety of structure types (e.g., the hcp derivative olivines, the $c c p$ spinels, and the hexagonal phenakite structure). The temperature dependence of the critical amorphization dose, $\mathrm{D}_{\mathrm{c}}$ for many of the $\mathrm{A}_{2} \mathrm{BO}_{4}$ compositions was investigated by in situ TEM during ion beam irradiation in order to investigate structural and honding controls on the amorphization and recovery processes. The phases studicd so lar include: forsterite $\left(\mathrm{Mg}_{2} \mathrm{SiO}_{4}\right)$, fayalite $\left(\alpha-\mathrm{Fe}_{2} \mathrm{SiO}_{4}\right)$, phenakite $\left(\mathrm{Be}_{2} \mathrm{SiO}_{4}\right)$, synthetic $\mathrm{Mg} 2 \mathrm{GeO}_{4}$, spinel 
$\left(\mathrm{MgAl}_{2} \mathrm{O}_{4}\right)$, chromite $\left(\mathrm{FeC} \mathrm{r}_{2} \mathrm{O}_{4}\right)$ and $\gamma$-SiFe2 $\mathrm{O}_{4}$ a a spinel pluase formed at high pressure. Among these phases, $\mathrm{Mg}_{2} \mathrm{SiO}_{4}, a-\mathrm{Fe}_{2} \mathrm{SiO}_{4}, \mathrm{Mg}_{2} \mathrm{GeO}_{4}$ have the olivine struclure, and $\mathrm{Mg}_{2} \mathrm{SiO}_{4}, \alpha-\mathrm{Fe}_{2} \mathrm{SiO}_{4}$ are the end-members of a complete solid-solution $\left(\mathrm{Mg}, \mathrm{Fe}_{2}\right)_{2} \mathrm{SiO}_{4}$ series (scveral intermediate compositions of this series have also hecn studied at room tempcrature). The olivine stucture (Pbnm) is an orthorhombic derivative of $h c p$ of the oxygens; $\mathrm{Mg}$ and $\mathrm{Fe}$ are in octahedral coordination and $\mathrm{Si}$ in tetrahedral coordination (Fig. 6). The $\mathrm{SiO}_{4}$ tctrahedral monomers are isolated from onc another, but are joined along three edges and one apex to the edge-sharing chains (parallel to $c$ ) of A-site octahedra. In $\mathrm{Mg}_{2} \mathrm{GeO}_{4}$, Ge substitutes for $\mathrm{Si}$ in tetrahedral sites, but the increased covalency of the Ge-O bond leads to lengthening of the shared edges. Phenakite $\left(\mathrm{Be}_{2} \mathrm{SiO}_{4}\right)$ is trigonal, and the $\mathrm{A}$ - and $\mathrm{B}$-site cations are in tctrahedral coordination. The tetrahedra form comer-sharing 6- and 4-membered rings (perpendicular to c); Be and $\mathrm{Si}$ atoms atternatc. The rings are stacked (parallel to $c$ ) to form a comer-sharing three dimensional network. $\mathrm{MgAl}_{2} \mathrm{O}_{4}, \mathrm{FCCr}_{2} \mathrm{O}_{4}$ and $\gamma-\mathrm{SiFe}_{2} \mathrm{O}_{4}$ all have the spinel structure ( $F d 3 m ; Z=8$ ), which, with the general formula of $\gamma_{0} \mathrm{VT}_{A} \mathrm{~A}_{2} \mathrm{NBO}_{4}$, is a face-centered ccp structure in which $1 / 8$ of the tetrahedral sites and $1 / 2$ of the octahedral sitcs are occupicd by $A-$ and $B-$ site cations, respectively.

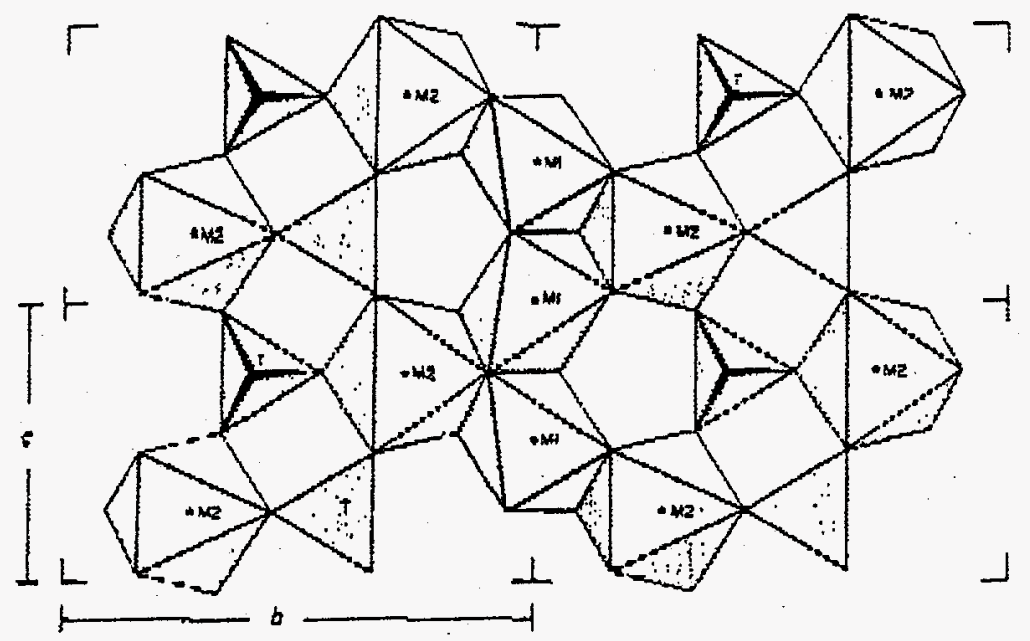

Figure 6. Structure of olivine as scen down [100] axis. Si atoms are in tetrahedral sites. Mg and $\mathrm{Fe}^{2+}$ are in $\mathrm{M} 1$ and $\mathrm{M} 2$ octahedral sites. Oxygen atoms arc at the comers of the polyhedra [39].

The temperature dependence of the critical doses required for amorphization, $D_{c}$ (in dpa), for five $\mathrm{A}_{2} \mathrm{BO}_{4}$ phases, $\mathrm{Mg}_{2} \mathrm{SiO}_{4}, \alpha-\mathrm{Fe}_{2} \mathrm{SiO}_{4}, \mathrm{Mg}_{2} \mathrm{GeO}_{4}, \mathrm{Be}_{2} \mathrm{SiO}_{4}$ and $\gamma-\mathrm{SiFe}_{2} \mathrm{O}_{4}$ under 1.5 $\mathrm{McV} \mathrm{Kr}$ ion beam irradiation are plotted in Fig. 7. The $D_{\mathcal{c}}$ 's arc comparable at $15 \mathrm{~K}$ for all five phases $(0.2-0.5 \mathrm{dpa})$, but $D_{\mathrm{c}}$ increascs with tempcrature at different rates. During ion beam irradiation, two competing processcs, amorphization and relaxation/annealing occur dynamically. Although the diffusion driven rccovery is increased by imradiation-enhanced diffusion, this process is suppressed at low temperatures. Thus, the analysis of the tempcrature dependence of the critical amorphization dose. $D_{\mathcal{c}}$, allows the two processes to be examined

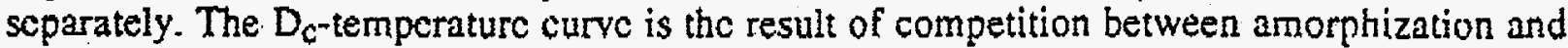
dynamic recovery processes. While $D_{c}$ increases with the incrcasing temperaturc in gencral, the slope of the $D_{\mathfrak{c}}$-temperature curve is indicative of a material's ability to recover. The $D_{\mathcal{c}}$ rate of increase (highest to lowest) is, as shown in Fig. 7: Be2SiO4, $\mathrm{MveSiO}_{4}, \mathrm{Mg}_{2} \mathrm{GeO}_{4}$, $\alpha$ $\mathrm{Fe}_{2} \mathrm{SiO}_{4}$ and $\gamma-\mathrm{SiFe}_{2} \mathrm{O}_{4}$. The differences in the recovery rates change with temperature and results in the differcnces in amorphization "rcsistance" at clevated tomperatures. Thus, the previous order for the $D_{\mathcal{c}}$ rate of increasc can also be regarded as a relative ranking of "resistancc" to amorphization at elcvated temperalures. More accurately, the material's relative 


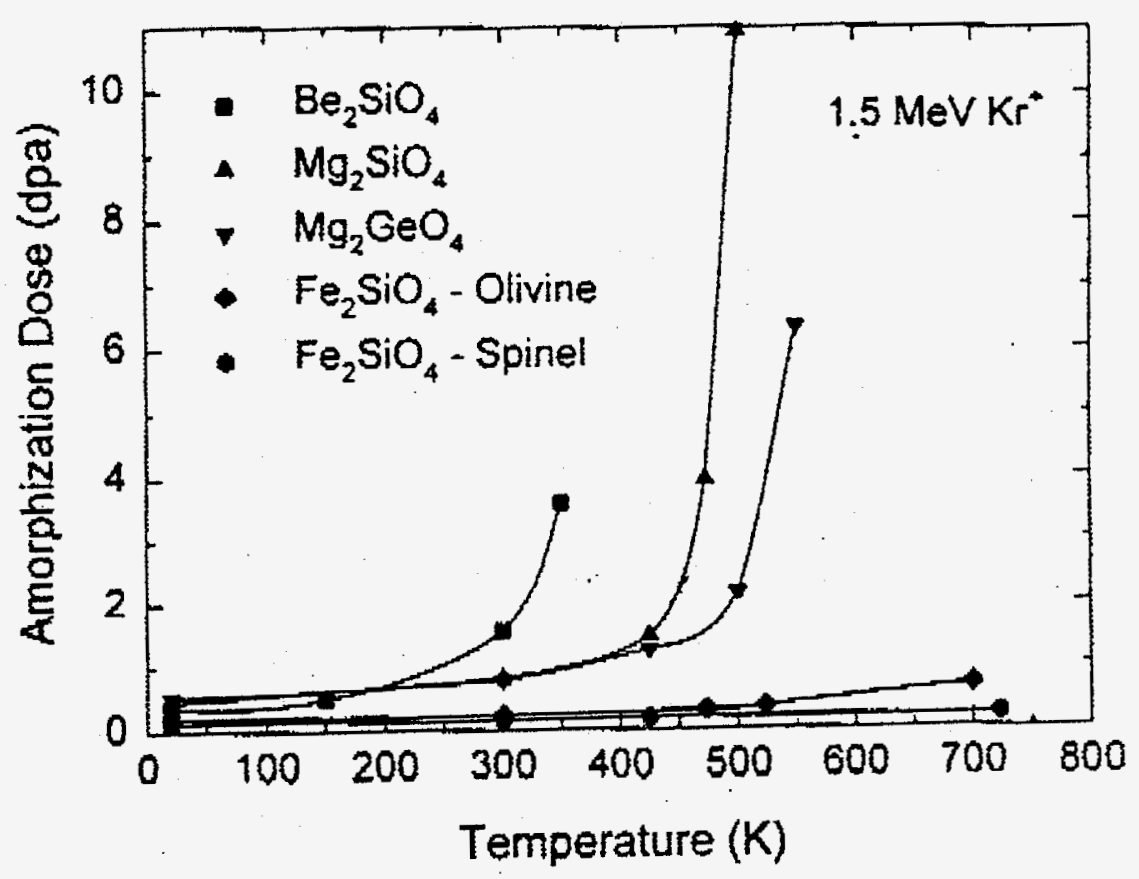

Figure 7. Temperature dependence of critical amomhizatiun dose of five $\mathrm{A}_{2} \mathrm{BO}_{4}$ phases under $1.5 \mathrm{MeV} \mathrm{K}+$ irradiation.

resistance to amorphization is a measurc of a matcrial's capability to recover when amorphized by displacement damage.

Data for the two spind compositions, $\mathrm{MgAl}_{2} \mathrm{O}_{4}$ and $\mathrm{FeCr}_{2} \mathrm{O}_{4}$, were not included in Fig. 7 hecause $\mathrm{MgAl}_{2} \mathrm{O}_{4}$ was not amomhizad al tempcralures as low as $20 \mathrm{~K}$ al a dose as high as 7.5 dpa; $\mathrm{FeCr}_{2} \mathrm{O}_{4}$ amorphized at $20 \mathrm{~K}$, but only at a dose of -5 dpa which is more than ten times higher than that for the materials plotted in Fig. 7. Recently, Yu et al. [36] reported $400 \mathrm{kV}$ $\mathrm{Xe}^{+}$ion-induced amorphization of $\mathrm{MgAl}_{2} \mathrm{O}_{4}$ at $100 \mathrm{~K}$; however, the dose was $25 \mathrm{dpa}$, and the implanted $X e$ ions in the damage layer may have played a role in the amotphization. The unique amorphization resistance shown by the spinel structurc is discussed in a separate paper in this proceedings [37].

Although the valucs fur $D_{\mathcal{C}}$ are deternined by electron diffraction at the maximum clectron transparent thickness (with $300 \mathrm{kV}$ electrons) [38], high resolution TEM has also been conducted on samples irradiated at various ion doscs. The results for forsterite confirmed the cascade driven, heterogeneous nature of the amorphization process.

Table 1 lists important materials parameters which can be related to the amorphization of the $\mathrm{A}_{2} \mathrm{BO}_{4}$ phases studied (listed in order of increasing amorphization "resistance").

Table 1. Materials parameters of the $\mathrm{A}_{2} \mathrm{BO}_{4}$ phases in this study (phases are listed in the order of increasing amorphization "resistance").

\begin{tabular}{|c|c|c|c|c|c|c|}
\hline Phase & $\Delta \mathrm{G}_{\mathrm{f}}^{\circ}$ & Innicity & $\mathrm{O}-\mathrm{O}(\mathrm{A})$ & $\beta(\mathrm{Mhar})$ & $\mathrm{dB}_{\mathrm{A}} / \mathrm{d}_{\mathrm{A}}$ & $\Phi$ \\
\hline$y-\mathrm{Fe}_{2} \mathrm{SiO}_{4}(\mathrm{sp})$ & 1 & 0.504 & 2.965 & $/$ & 1.294 & 0.383 \\
\hline$\alpha-\mathrm{Fe}_{2} \mathrm{SiO}_{4}(\mathrm{ol})$ & -1379.4 & 0.504 & 3.049 & 146 & 1.324 & 0.383 \\
\hline $\mathrm{Mg}_{2} \mathrm{GeO}_{4}(\mathrm{ol})$ & 1 & 0.658 & 1 & 138 & 1 & 1 \\
\hline $\mathrm{Mg}_{2} \mathrm{SiO}_{4}(\mathrm{ol})$ & -2051.3 & 0.668 & 2.944 & 135 & 1.294 & 0.295 \\
\hline $\mathrm{Be}_{2} \mathrm{SiO}_{4}(\mathrm{ph})$ & -2033.7 & 0.554 & 2.750 & 66 & 1 & 0.177 \\
\hline $\mathrm{Cr}_{2} \mathrm{FeO}_{4}(\mathrm{sp})$ & 1 & 0.574 & 1 & 107 & 1 & 0.292 \\
\hline $\mathrm{Al}_{2} \mathrm{MgO}_{4}(\mathrm{sp})$ & -2174.9 & 0.629 & 2.792 & 96 & 1.001 & 0.198 \\
\hline
\end{tabular}


The meaning of the parameters and their relatiunship to the relativg amorphization mosistance of the phuses are liscussed as follows:

$\Delta G^{\circ} f$ is the standard free energy of formation from pure elernents at $298 \mathrm{~K}$. With the exception for $\mathrm{Be}_{2} \mathrm{SiO}_{4}$, the phase with the lower value of $\wedge \mathrm{G}^{\circ}$, or a phase more themodynamically stable, is more resistont to amorphization at the elevated temperatures.

The ionicity, calculated by Pauling's equation, is a measure of the avorage bond type. For a given crystal structure, the phase with the higher ionicity is mon "resistant" to amophication at elevated temperatures. This confims the results of a previous study on five different $\left[\left(\mathrm{Mg}, \mathrm{Fe}_{2}\right)_{2} \mathrm{SiO}_{4}\right]$ compositions irradiated with $1.5 \mathrm{MeV} \mathrm{K}{ }^{+}$at room tempcrature [39]. Note, in comparisons between structure types, this criterion does not work.

Average $\mathrm{O}-\mathrm{O}$ distances provide an indication of the resistance to distuption between polyhedra in structure. In general, resistance to amorphization should increase with decreasing $\mathrm{O}-\mathrm{O}$ distance. This is basically confirmed by the data in Table 1 ; however, because $\gamma-\mathrm{SiFe}_{2} \mathrm{O}_{4}$ was formed under high pressure and is thermodynamically metastable, the small $0-O$ distance is an unstable, high pressure configuration. As noted by Zemann [40], phenakite has the lowest interpolyhedral O-O distance among the silicates $(2.75 \hat{\mathrm{A}})$. Phenakite is, thus far, the silicate with the highest "resistance" to ion bcam-induced amorphization. $\mathrm{Al}_{2} \mathrm{MgO}_{4}$ has a larger average $\mathrm{O}-\mathrm{O}$ distance than $\mathrm{Be}_{2} \mathrm{SiO}_{4}$; yet exhibits higher amorphization "resistance" because the oxygen atoms are in a near perfect ccp array.

The average $\mathrm{M}-\mathrm{O}$ bond compression coefficient, $\beta$, is a quantitative indication for the bond strengths in the structure (inverse of the bond strength value). Within a structure type, "resistance" to amorphization increases with decteasing $\beta$ because a strongcr bond has a high tendency to recover when broken. The lowest $\beta$ valuc among the listed phases is that of phenakite. However, the crystal structure of phenakite only consists of $\mathrm{BeO}_{4}$ and $\mathrm{SiO}_{4}$ tetrahedra, while the crystal structures of spinel and olivine are comprised of BO6 octahedra and $\mathrm{AO}_{4}$ tetrahedra. Their structural topologies are quite differcnt. Thesc data emphasize the importance of structure type (between comparable compositions) in evaluating the relative "resistance" to amorphization.

The parametcr, $\mathrm{dB} / \mathrm{dA}$, is the ratio between $\mathrm{M}-\mathrm{O}$ distances in the tctrahedral and octahedral sites. This parameter quantifies the relative stability of spincl or olivine structure types $\left(\mathrm{A}_{2} \mathrm{BO}_{4}\right)$. For instance, if $\mathrm{dB} / \mathrm{dA}$ is less than 1.19 , then the spinel structute is stable. At higher values the olivine structure is stable at normal pressures [41]. This ratio for $\gamma$ - $\mathrm{Fe}_{2} \mathrm{SiO}_{4}$ is 1.294 ( $>$ 1.19). Thus, topologically this high pressure phase is not stable, and a lower "resistance" to ion-beam induced amomhization is expected (although it has the spinel structure). Finally, based on the similar amorphization doses between $\alpha-\mathrm{Fe}_{2} \mathrm{SiO}_{4}$ and $\gamma-\mathrm{Fc}_{2} \mathrm{SiO}_{4}$ (Fig. 7), similar compositions may be more important than the difference in structure type in determining the critical amorphization dose.

The structural deviation parameter, $\Phi$, [defined in ref. 37 ], is a measure of the deviation from perfect $c c p$ and $h c p$ of the oxygen anions. Distortion (resulting from cations which do not fit perfectly into the tetrahcdral and octahedral interstices) of the perfect anion packing contributes to the relative instability of the structure. For an ideal spincl structure, $\Phi$ equals to zero. With the exception for $\mathrm{BcO}_{4}$, which does not have occupied octahedral sitcs in the structure, the resistance to amorphization docs indeed increase with decrcasing $\$$. We note that this type of analysis may not only apply to a considcration of ion-beam induccd amorphization, but it might also be applicd to other amorphization processes. For example, the pressurc requircd to amorphize various (Fe, Mg)-olivine compositions also increases with the increasing $\mathrm{Mg}$-content in the pressurc-induced amorphization of olivine [42].

Finally, the slope of the $D_{c}$-temperature curves is also a function of the density of the material. The lower the target density, the faster the curve rises (resulting in a lower activation energy for recovery and lower critical amorphization temperature). The effect of the lower target density is similar to the observations of Koike et al. $[43]$ on the effect of smaller projectilc-mass on the amorphization dose for CuTi. This dependence and similarity can be 
qualitatively explained in terms of the collision cascade size. For a fixed target, the crnsssection for nuclear collision is larger when a grcater projectile mass is used, thus, crexting a larger displacement cascade. The samc relation is true for a fixed projectile mass in a target of greater density. As shown in ref. [38]. the per ion vacancy production in at $200 \mathrm{~nm}$ thick foil varied from 2,200 for $\mathrm{Be}_{2} \mathrm{SiO}_{4}\left(2.96 \mathrm{y}_{\mathrm{cm}}^{3}\right)$ to 3,500 for $\mathrm{Fe}_{2} \mathrm{SiO}_{4}\left(4.392 \mathrm{~g} / \mathrm{cm}^{3}\right)$. 'The greater the vacancy production per inn, the larger the displacement cascade. Because the activation energies for the recovery process calculuted by the Weber et al. mudel [18] for these $\mathrm{A}_{2} \mathrm{BO}_{4}$ phases $(<0.1 \mathrm{eV})$ are too low for crystal nucleation (usually several $\mathrm{eV}$ ), it is assumed that the recovery in the amorphous cascade region was mainly through the epitaxial regrowth of the surrounding crystalline volume [38]. The recovery rate for a smaller cascade (smaller amorphous domain) is faster than that of a larger one because the surface area to volume ratio is larger for smaller cascades, thus allowing more cfficient cpitaxial recrystallization (i.e., shrinkage of the amorphous volume). With this consideration, the effects of other matcrial parameters listed in Table 1 may be overestimated.

In summary, thruugh the analysis on temperature dependence of amorphization dose for seven $\mathrm{A}_{2} \mathrm{BO}_{4}$ phases, we find that the structure type is important in determining the amorphization "resistance", with the exception noted for $\alpha-\mathrm{Fe}_{2} \mathrm{SiO}_{4}$ and $\gamma-\mathrm{Fe}_{2} \mathrm{SiO}_{4}$. Within a single structure type, many material parameters can be indicative of a matcrial's "resistance" to amorphization; however, these criteria cannot be applied to the comparison of different structure types.

\section{CONCLUSIONS}

This brief survey of radiation effects in "complex" ceramics illustrates that the complexity in compositions and diversity in structure types is amcnable to systematic studies which allow an analysis of the role of structural topology and bonding on the damage microstructure of this class of materials. The comparison to natural materials of similat compositions and structures that have accumulated cquivalent doscs over longer periods of time (e.g., hundreds of millions of years) provides a unique opportunity to study dose rate effccts which may vary by as much as eight or nine orders of magnitude. Such studies have specific applications to the study of the long-tem durability of ceramic nuclear wastc forms.

\section{ACKNOWLEDGMENTS}

The authnrs gratefully acknowlcdge the cuntinuing support of the Office of Basic Encrgy Sciences, DOE, for the work summarized in this paper (DE-FG03-93ER45498 to RCE and DE-AC06-76RLO 1830 to WJW). The experiments and observations summarized in this paper have been the result of time-consuming expcriments and collaborations that would not have been possible without the continuity of support provided by BES. We particularly thank Dr. W.L. Gong for fruitul discussions and review of portions of this manuscriph

\section{REFERENCES}

1. H.M. Naguib and R. Kelly, Radiation Effects 24, 1 (1975).

2. A. Pabst, Amcrican Mineralogist 37, 137 (1952)

3. R.C. Ewing, B.C. Chakoumakos. G.R. Lumpkin and T. Murakami, Mater. Res. Soc. Bull. 12(4), 58 (1987).

4. R.C. Ewing, Nucl. Instru. Moth. in Physics Res. B91, 22 (1994).

5. G.R. Lumpkin and R.C. Ewing, Physics and Chemistry of Mincrals 16, 2 (1988).

6. W.J. Weber, J. Mater. Res. 5,2687 (1990). 
7. T. Murakami, B.C. Chakoumakns, R.C. Ewing. G.R. Lumpkin and W.J. Weber, American Mincralogist 76, 1510 (1991).

8. L.M. Wang, R.K. Ehy, J. Janeczek and R.C. Ewing, Nucl. Instru. Meth. Physics Res. B59/60, 395 (1991).

9. L.M. Wang and R.C. Ewing, Mat. Res. Snc. Bull. XVII, 38 (1992).

10. R.K. Eby, R.C. Ewing and R.C. Birtcher, J. Mater. Res. 7, 3080 (1992).

11. A.N. Sreeram and L.W. Hobbs, this volume.

12. Hj. Matzke, Radiation Effects 64, 3 (1982).

13. R. Devanathan, N.Q. Lam, P.R. Okamoto, M.J. Sabochick, and M. Mcshij, Juumal of Alluys and Cumpounds 194, 447 (1993).

14. N.Q. Lam and P.R. Okamoto, Surface and Coatings Technology 65, 7 (1994).

15. N.Q. Lam and P.R. Okamoto, MRS Bulletin XIX(7), 41 (1994).

16. H.D. Holland and D. Gottfried, Acta Crystallogr. 8, 291 (1955).

17. W.J. Weber, J. Amer. Ceram. Soc. 76, 1729 (1993).

18. W.J. Webcr, R.C. Ewing, and L.M. Warg, J. Mater. Rcs. 9, 688 (1994).

19. L.M. Wang, R.C. Ewing, W.J. Weber, and R.K. Eby, in Bcarn-Solid Intcractions: Fundamentals and Applications, edited by M.A. Nastasi, N. Herbots, L.R. Harriott, and R.S. Averback (Mater. Res. Soc. Symp. Proc. 279, Pittsburgh, PA, 1993) p. 451.

20. A.B. Harker and J. F. Flintoff, in Scientific Basis for Nuclear Waste Management VII, G.L. McVay, Ed. (North Holland, New York, 1984) p. 513.

21. D McConnell, Apatite (Springer-Verlag, New York, 1973).

22. D.G.A. Nelson, J.D. McLean, and J.V. Sanders, Radiat. Effects Lett. 68, 51 (1982),

23. M. Cameron. L.M. Wang, K.D. Crowley, and R.C. Ewing, in Proc. 50th Annual Mceting the Electron Microscope Society of America, G.W. Bailey, J. Bentley, and J.A. Small, Eds. (San Francisco Press, San Francisco, 1992) p. 378.

24. L.M. Wang, M. Cameron, W.J. Weber, K.D. Crowley, and R.C. Ewing, in Hydroxyapatite and Related Compounds. P.W. Brown and B. Constantz, Eds. (CRC Press, Boca Raton, FL, 1994) p. 243.

25. W.J. Weber, R.P. Turcotte, L.R. Bunncll, F.P. Roberts, and J.H. Westsik, Jr., in Ceramics in Nuclear Waste Managemcnt, cditcd by T.D. Chikalla and J.E. Mendel (NTIS, Springfield, VA, 1979) p. 294.

26. R.P. Turcore, J.W. Wald, F.P. Ruberts, J.M. Rusin, and W. Lutze, J. Amer. Ceram. Soc. 65, 589 (1982).

27. W3. Weber, Radiation Effects 77, 295 (1983).

28. W.J. Weber and L.M. Wang, Nucl. Instr, and Meth. B91, 63 (1994).

29. B.C. Chakoumakos, J. Solid State Chem. 53, 120 (1984).

30. R.C. Ewing, W.J. Weber and F.W. Clinard, Jr., Progress in Nuclear Energy, in press.

31. W.J. Weber, R.P. Turcottc, F.P. Roberts, Radioactive Waste Management 2(3), 295 (1982).

32. T.J. White, R.C. Ewing, L.M. Wang, J.S. Fortester, C. Montross, in Scientific Basis for Nuclear Wastc Management XVIII, T. Murakami and R.C. Ewing, Eds. (Matcrials Research Society, Pittsburgh, in press).

33. R.C. Ewing and L.M. Wang, Nucl. Instr. Meth. in Physics Res. B65, 319 (1992).

34. T.J. Headley, G.W. Amold, C.J.M. Northrup, in Scientific Baiss for Radioactive Wastc Management V, W. Lutze, Ed. (Materials Research Society, Pituburgh, 1982) pp. 379388.

35. F.W. Clinard, Jr, D.E. Peterson, and D.L. Rohr, J. Nucl. Mater. 126. 245 (1984).

36. N. Yu, K.E. Sickafus and M. Nastasi, Phil. Mag. Lett. 70, 235 (1994).

37. L.M. Wang, W.L. Gong, N. Bordes, R.C. Ewing and Y.Fei, this volume.

38. L.M. Wang, W.L. Gong and R.C. Ewing, Mat. Res. Suc. Symp. Proc. 316, 247 (1994).

39. L.M. Wang and R.C. Ewing, Mat. Res. Soc. Symp. Proc. 235.333 (1992).

40. J. Zemann, Z. Kristallogr. 175, 299 (1986).

41. R.M. Hazen and A.T. Prewitt, American Mincralogist 62.309 (1977).

42. F. Guyot and B. Reynard, Chemical Gculogy 96,4I1 (1992).

43. J. Koike, P.R. Okamoto and L.E. Rehn, J. Mater, Res. 4. I143 (1989). 